\title{
Sosyal Bilgiler Öğretmenlerinin Literatürdeki Sosyal Bilgiler Dersi Kavram Yanılgılarına İlişkin Görüşleri
}

\author{
Ülkü Tuğçe ÇAL PEKTAŞı
}

Geliş Tarihi: 27.10 .2021

Kabul Tarihi: 07.12.2021

Doi: $10.47503 /$ jirss.1015043

\section{Özet}

$\mathrm{Bu}$ araştırmanın amacı sosyal bilgiler öğretmenlerinin literatürdeki sosyal bilgiler dersi kavram yanılgılarına ilişkin görüşlerini ortaya koymaktadır. Nitel araştırma yöntemi ile yapılan bu araştırmada nitel araştırma desenlerinden olgu-bilim deseni kullanılmıştır. Araştırma Milli Eğitim Bakanlığı'na bağlı ortaokullarda görev yapan 22 sosyal bilgiler öğretmeni ile yürütülmüştür. Bu araştırmadan elde edilen veriler, yarı-yapılandırılmış görüşme formu ile toplanmıştır. Katılımcı öğretmenlere ilgili literatür taranarak ve uzman görüşleri alınarak 11 soru yöneltilmiştir. Elde edilen veriler içerik analizi tekniğiyle incelenmiştir. Araştırma bulgularından elde edilen sonuçlara göre katılımcı sosyal bilgiler öğretmenleri sosyal bilgilere dersine ait kavramlara yönelik öğrencilerin "milli egemenlik", "bağımsızlık" kavramları başta olmak üzere "paralel, meridyen, kuzey yarım küre, güney yarım küre, kutup dairesi" gibi soyut coğrafi kavramları da öğrenmede güçlük yaşadıkları ve kavram yanılgılarına sahip olduğu tespit edilmiştir. Tespit edilen bu sonuç literatürdeki araştırmaların sonuçlarıyla paralellik göstermektedir. Katılımcı sosyal bilgiler öğretmenlerin kavram yanılgılarını tespit edebilme ve bu kavram yanılgılarının düzeltilmesi noktasında kavram öğretimine yönelik yöntem ve teknik bilgilerinin eksik olduğu sonucuna ulaşılmıştır.

Anahtar Kelimeler: Kavram öğretimi, Kavram yanılgısı, Sosyal bilgiler eğitimi, Sosyal bilgiler öğretmen görüşleri

\footnotetext{
${ }^{1}$ Arş. Gör., Akdeniz Üniversitesi Eğitim Bilimleri Enstitüsü, Türkiye. tugcecal4@gmail.com ORCID: https://orcid.org/0000-0003-2902-8229

Atıf künyesi: Çal Pektaş, Ü. T. (2021). Sosyal bilgiler öğretmenlerinin literatürdeki sosyal bilgiler dersi kavram yanılgılarına ilişkin görüşleri. Journal of Innovative Research in Social Studies, 4(2), 102-120. 


\title{
Opinions of Social Studies Teachers on Social Studies Course Misconceptions in the Literature
}

Received Date: 27.10 .2021

Accepted Date: 07.12.2021

Doi: 10.47503/jirss.1015043

\begin{abstract}
The aim of this research is to reveal the opinions of social studies teachers about the misconceptions of social studies course in the literature. The research was conducted with 22 social studies teachers working in secondary schools affiliated to the Ministry of National Education. In this study, which was conducted with the qualitative research method, the phenomenology pattern, one of these qualitative research patterns, was used. The data obtained from this research were collected with a semi-structured interview form. 11 questions were asked to the participating teachers by scanning the relevant literature and taking expert opinions. The obtained data were analyzed by content analysis technique. According to the results obtained from the research findings, the participating social studies teachers used abstract geographical concepts such as "parallel, meridian, northern hemisphere, southern hemisphere, polar circle", especially the concepts of "national sovereignty", "independence" of the students for the concepts of the social studies course. It has been determined that they have difficulties in learning and have misconceptions. It has been concluded that participatory social studies teachers lack method and technical knowledge of concept teaching in terms of identifying misconceptions and correcting these misconceptions.
\end{abstract}

Keywords: Concept teaching, Misconception, Social studies education, Social studies teacher opinions 


\section{GİRIŞ}

Kavramlar insanları olayları, olguları, ideaları, benzer nesneleri süreçleri gruplayan kategoridir. Düşünebilmek için kavramlar gereklidir. Bireylerin olay, fikir, varlıklar ve süreçleri diğer gruplardan ayırt etmesini ve ilişkiler kurmasını sağlar. Kavramları anlayabilmek problem çözme ve üzerinde yaşadığımız dünyayı anlayabilmek için gereklidir (Senemoğlu,2007). Kavramlar bir konuyu, olguyu anlayabilmenin yapı taşıdır. Kavramlar, bir insanın yaşamı boyunca düşüncenin temel yapısıdır (Preter, 1993). Erden ve Akman (1997)'a göre kavram insanların, nesne, obje, olaylarla ile ilgili düşünebilmesi ve bilgi edinmesi için öncelikle bu nesnelerin bir adı olması gerekmektedir. Bu sebeple benzer özelliklere sahip düşünce ve nesnelere bir ad verilerek gruplamalar oluşturulmaya gidilmiştir. Ülgen (2001)'e göre ise kavram bireyin zihninde anlam kazanmış farklı olgu ve nesnelerin farklılık gösteren ortak özelliklerini kapsayan ve bir sözcükle ifade edilen bilgi şeklidir. TDK (2019)'da "Bir nesnenin veya düşüncenin zihindeki soyut ve genel tasarımı, mefhum, fehva, konsept, nosyon" şeklinde tanımı yapılmıştır. Kılıçoğlu (2011) tüm kavram tanımlamalarının ortak noktasının kavramların anlamlı öğrenmeyi gerçekleştirmede etkili olduğunu, öğrencilerin başarısını pozitif yönde etkilediğini ifade etmiştir.

Kavram öğrenme uyaranları kategorize ederek, zihinde bilgiler oluşturmadır. Bireyler hayat boyu yeni kavramlarla ya da aynı kavramla farklı seviyelerde ve farklı konumlarda karşılaşabilirler (Ülgen, 1996). Kavram öğretimini etkileyen birçok etken vardır. Bunlar; bireyin gelişim özellikleri, kavramın yapısı, bireyin ailesinin sosyo-ekonomik yapısı, okul ortamı, öğretmen özellikleri, bireyin sahip olduğu sözcük dağarcığı vb. bunlar kavram öğretiminde önemlidir. Türkiye'de ve dünyada yapılan araştırmalarda öğrencilerin ders ortamına girmeden öncesinde ve sonrasında kavramlarla ilgili bir takım yanlış düşünceler içerisinde bulundukları tespit edilmektedir (Tokcan,2015). Bu tür düşünceleri ifade etmek için kavram yanılgısı (misconception) terimi kullanılmaktadır. Kavram yanılgısı, bir bireyin bir kavramı anladığı biçimin, ortaklaşa kabul edilen bilimsel anlamından önemli derecede farklılık göstermesi olarak tanımlanmaktadır (Marioni, 1989; Tery, Jones ve Hurford, 1985; Riche, 2000; Stepans, 1996; aktaran; Aydoğan, Güneş ve Gülçiçek, 2003). Kavram yanılgıları kişisel deneyimler sonucuyla oluşan, bilimsel gerçeklere ve düşüncelere aykırı, anlamlı öğrenmeyi engelleyici bilgilerdir (Borozan, 2008 s.14). Piaget kavram yanılgilarını birbiri üzerine eklenen bir yapıya benzetmektedir. Önce bilgi eksikliğinden ortaya çıkan bir boşluk gibi başlayarak bu boşluk öğretmenin verdiği niteliksiz eğitim, öğrencilerin mevcut bilgileri ve karşılaşılan deneyimlerle rastgele dolmaktadır. Bu olay kavram yanılgısı olarak karşımıza çıkmaktadır (Tokcan, 2015).

Kavram yanılgıları sosyal bilgiler eğitimi için önemli bir meseledir. Özellikle sosyal bilgiler öğretiminde bazı kavramların soyut yapısından dolayı çok sık karşılaşılmaktadır. Bu sebeple hedeflenen amaçlara uygun öğretimi engelleyici bir durum ortaya çıkmaktadır. Sosyal bilgiler dersinin temel amacı olan hayatta gerekli bilgi ve becerilere sahip etkin vatandaşlar yetiştirilebilmesi sosyal bilgiler derslerindeki kavram öğretiminin etkililiği ve yeterliliği ile mümkün olmaktadır. Bu nedenle sosyal bilgiler eğitimi alanında yapılan kavram yanılgısı çalışmaları ve bu çalışmalarla öğrencilerin kavram yanılgılarının incelenmesi, öğretmenlerin gözlemleri ve görüşlerinin alınması önem arz etmektedir. Bu bağlamda bu araştırma kapsamında literatürde yer alan sosyal bilgiler eğitimi kavram yanılgısı çalışmaları incelenmiştir. 
İlgili alan yazın incelendiğinde sosyal bilgiler öğretimi alanında çok sayıda kavram yanılgısı çalışmalarının olduğu görülmektedir. Sosyal bilgiler öğretim programında yer alan; "Paralel" "Meridyen", Kutup dairesi, Kutup noktası, Güney Yarım Küre, Kuzey Yarım Küre, Özel Konum, Matematiksel konum, (Akbaş, 2002; Akdağ, 2010; Kayacan,2010; Gülüm, 2010; Bitlisli, 2014; Karacan \& Demirkaya, 2016; Gümüş \&Avc1 2016; Özdoğan, 2016; Memişoğlu \& Tarhan, 2016; Boz, 2019), "heyelan”, “erozyon” (Bozkurt, Akın ve Uşak, 2004; Pınar ve Akdağ, 2012; Açıkgöz, 2007; Yıllar, 2007; Demirkaya \& Karacan, 2016, Boz, 2019) "milli egemenlik", "bağımsızlık, (Sabancı, 2008; . Gençmehmetoğlu, 2009; Akış \& Bal, 2010; Bal \& Gök, 2011; Kaya, 2011, Ünlü, 2011;) "fetih" “iskân” (Yılmaz \& Çiviler 2012; Akgün, 2014; Ayana, 2018) kavramlarıyla ilgili sosyal bilgiler öğrencilerinin kavram yanılgılarına sahip olduğu tespit edildiği görülmüştür. Bu bağlamda bu araştırmanın hedefi literatürde yer alan sosyal bilgiler öğretim programı içeriğinde yer alan bu kavramlara yönelik kavram yanılgılarının sosyal bilgiler öğretmenlerinin görüşlerine göre incelenmesidir. Öğretmenlerin sosyal bilgiler dersi öğretim programı içerisinde yer alan "paralel, meridyen, kutup dairesi, kutup noktası, Güney Yarım Küre, Kuzey Yarım Küre, özel konum, matematiksel konum, iklim, hava durumu, heyelan, erozyon, bağımsızlık, milli egemenlik, fetih, iskân” kavramlarına ilişkin “kavram yanılgısı" görüşlerinin incelenmesi bu kavram yanılgılarının kendi öğrencilerindeki durumlarına yönelik görüş ve deneyimlerinin incelenmesi hedeflenmiştir. Bu çerçevede aşağıdaki temel sorulara cevaplar aranmıştır:

1. Sosyal bilgiler öğretmenlerinin kavram yanılgısına ilişkin görüşleri nelerdir?

2. Sosyal bilgiler öğretmenlerinin sosyal bilgiler dersine ilişkin literatürde yer alan "paralel, meridyen”, “kutup dairesi”, “kutup noktası”, “Güney Yarım Küre”, "Kuzey Yarım Küre”, “özel konum", “matematiksel konum”, “heyelan”, “erozyon”, "milli egemenlik", "fetih", "iskân” kavramlarındaki öğrencilerin kavram yanılgılarına ilişkin görüşleri nelerdir?

3. Sosyal bilgiler öğretmenlerinin sosyal bilgiler dersine ilişkin literatürde yer alan "paralel, meridyen”, “kutup dairesi”, "kutup noktası”, "Güney Yarım Küre”, "Kuzey Yarım Küre”, “özel konum”, “matematiksel konum”, “heyelan”, “erozyon”, “milli egemenlik", "fetih", "iskân" kavramlarına ilişkin kavram yanılgısına sahip olan öğrencilerin kavram yanılgılarını düzeltme yöntemleri nelerdir?

\section{YÖNTEM}

Sosyal bilgiler öğretmenlerinin literatürdeki sosyal bilgiler dersi kavram yanılgılarına ilişkin görüşlerini belirlemeyi amaçlayan bu araştırma nitel araştırma yöntemi ile yapılmıştır. Bu araştırmada nitel araştırma desenlerinden olgu-bilim desenini kullanılmıştır. Olgu bilim araştırmaları kişi veya kişilerin bir yaşantıyı, olguyu nasıl deneyimledikleri ile ilgili açıklayıcı çalışmalardır. Olgu bilim araştırmalarında temel amaç kişi ya da kişiler için araştırılan olguya ait yaşantının ve deneyimin özü, anlamı ve yapısını ortaya çıkarmaktır. Bunun için araştırmacı kişilerin deneyimlerini ortaya çıkarmak adına derinlemesine görüşmeler gerçekleştirmektir (Sart, 2017). Olgubilim çalışmalarında araştırmacılar hipotezleri doğrulamaya veya çürütmeye çalışılmamaktadır. Elde edilen sonuçların ileride yapılacak araştırmalarda yeniden tartışılması ve incelenmesi için mevcut durum ortaya konularak sorgulayıcı bir temel oluşturulur (Smith \& Osborn, 2008). 


\section{Çalışma Grubu}

Bu çalışmaya Çorum İl Merkezi'nde ortaokullarda çalışan çalışmaya gönüllü 22 öğretmen katılmıştır. Bu çalışmada katılımcıların belirlenmesinde amaçlı olmayan örnekleme kapsamında ölçüt örneklem kullanılmıştır. Bu araştırmadaki, katılımcı öğretmenlerin belirlenmesinde temel ölçüt; Milli Eğitim Bakanlığı'na bağlı ortaokullarda sosyal bilgiler öğretmeni olarak görev yapan öğretmenlerin araştırmaya gönüllü olarak katılmasıdır. Katılımcı öğretmenlerin cinsiyet ve mesleki kıdem dağılımları Şekil 1 ve Şekil 2' de yer almaktadır

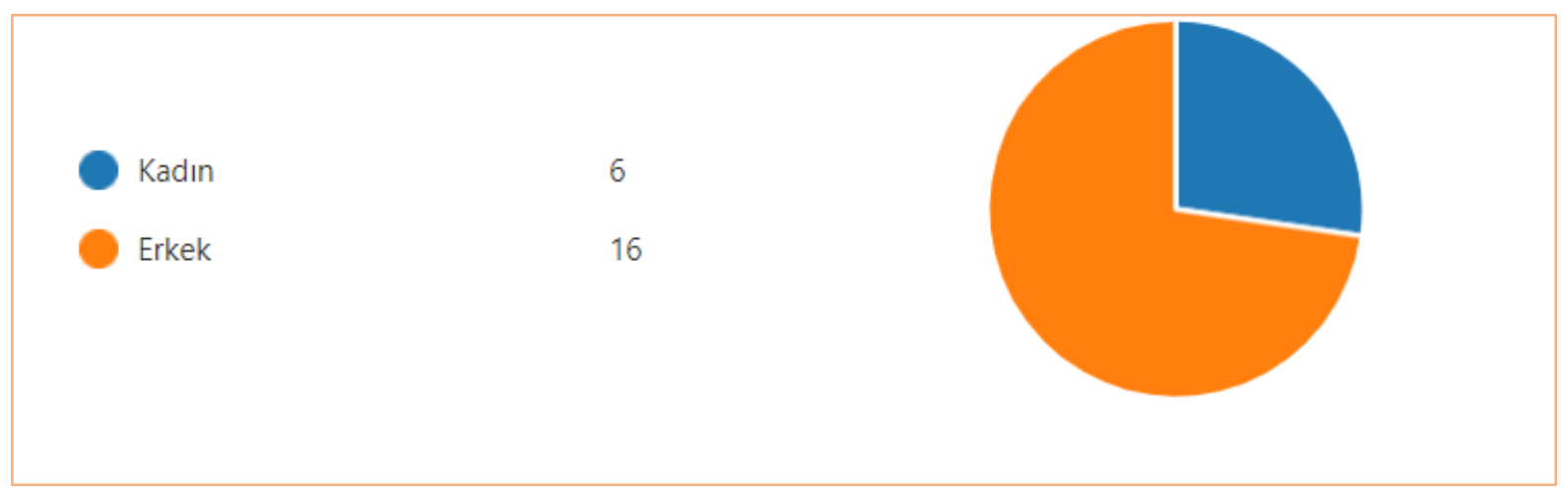

Şekil 1. Katılımcı öğretmenlerin cinsiyet dağılımı

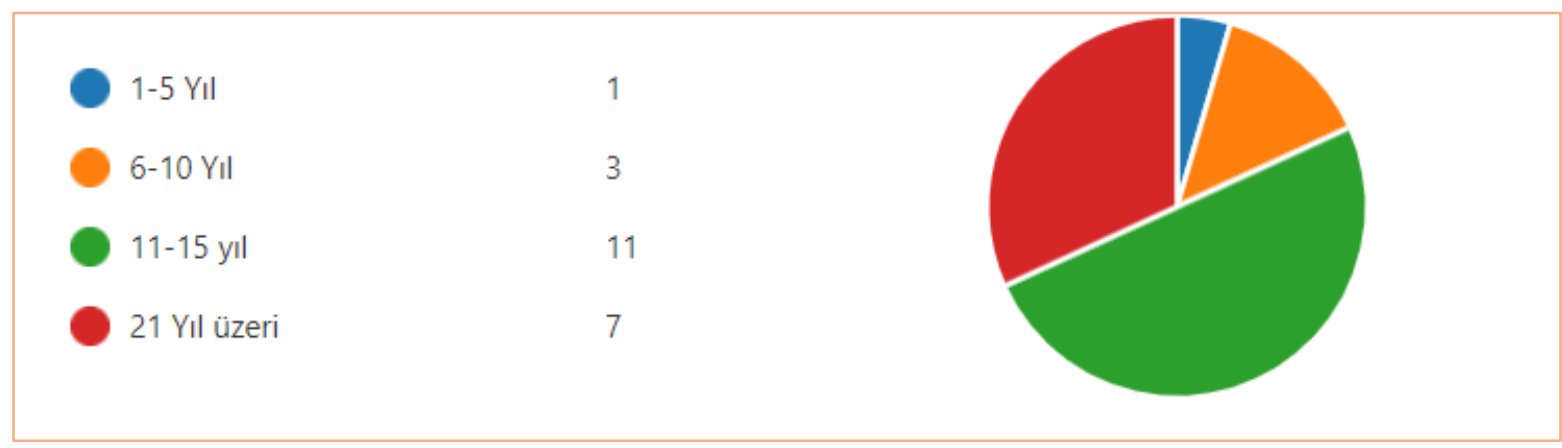

Şekil 2. Katılımcı öğretmenlerin mesleki kıdem dağılımı

\section{Veri Toplama Araçları}

$\mathrm{Bu}$ araştırmadan elde edilen veriler, yarı-yapılandırılmış görüşme formu ile toplanmıştır. Görüşme formunda yer alan görüşme soruları, ilgili literatür taranarak ve uzmanların görüşleri dikkate alınarak geliştirilmiştir. Görüşme formunda öğretmenlere kişisel bilgilerini doldurdukları bölümle (cinsiyet, mesleki kıdem) beraber kavram yanılgılarına yönelik sorular ve literatürde yer alan sosyal bilgiler dersine ilişkin 7 kavram yanılgısı sorusu sorulmuştur. Görüşme öncesinde katılımcıya araştırmanın içeriğinden bahsedilmiştir ve görüşmenin ses kayıt cihazı ile kayıt altına alınacağını ve bu kayıtların araştırmacı dışında kimse tarafından dinlenmeyeceği belirtilmiştir.

Görüşmeler Covid-19 pandemi süreci sebebiyle online görüşme olarak gerçekleştirilmiştir. Araştırmaya katılan katılımcıların gerçek isimleri gizli tutularak her bir katılımcıya ayrı bir kod verilmiştir. Görüşmeye öncesinde katılımcılar bu araştırmaya gönüllü olarak katıldıklarını beyan eden görüşme kılavuzunu imzalayıp e-mail yoluyla göndermişlerdir. 


\section{Verilerin Analizi}

$\mathrm{Bu}$ araştırmada toplanan veriler içerik analizi tekniğiyle analiz edilmiştir. "İçerik analizinde temel amaç, verileri açıklayabilecek kavramlara ve ilişkilere ulaşmaktır". İçerik analizi nitel araştırmalarda güvenirliği artırması sebebiyle önerilmektedir (Yıldırım ve Şimşek, 2018, s. 242). Nitel araştırmalarda içerik analizinde verilerin toplanmaya başlanmasıyla beraber analiz de başlamaktadır. İçerik analizinin basamakları şu şekildedir verilerin içerik analizine uygun olarak düzenlenmesi, kategoriler oluşturulması, kodlama formunun hazırlanması, tüm metnin kodlanması, kodlamanın tutarlılığının kontrole edilmesi, kodlanmış verilerden sonuç çıkarılması. Bu yöntem geçerlik ve güvenirliği sağlamada bir dizi şeffaf sistematik prosedürü kapsamaktadır (Güçlü, 2019 s. 176). Bu araştırmada Öncelikle her bir öğretmen için ayrı görüşme formu oluşturulmuş ve görüşmelerin dökümü yapılmıştır. Öğretmenlerin her bir soruya verdikleri yanıtlar anahtar kavramlarla kodlanmıştır. Elde edilen bulgular tablolar oluşturulup doğrudan alıntılara yer verilerek yorumlanmıştır. Araştırmanın güvenirliği artırmak amacıyla uzman görüşleri alınmıştır. Araştırmacı görüşüyle uzman görüşleri arasında karşılaştırma yapılmıştır. Her bir öğretmene ayrı bir kod verilmiştir.

\section{BULGULAR}

Bu bölümde araştırmadan elde edilen bulgular ve bu bulgulara ilişkin olarak yapılan yorumlar yer almaktadır. Araştırmada elde edilen bulgular ve yorumlar, çalışmanın alt problemleri doğrultusunda sunulmuştur.

\section{Araştırmanın Problemine Göre Katılımcı Öğretmenlerin Kavram Yanılgısının Tanımına İlişkin Görüşleri}

Katılımcı öğretmenlerin kavram yanılgısının tanımına ilişkin görüşleri Tablo 1'de verilmiştir.

\section{Tablo 1.}

Katılımcı öğretmenlerin kavram yanılgısının tanımına ilişkin görüşleri

\begin{tabular}{lcc}
\hline Tanımlar & Katı1ımcı No & $f$ \\
\hline Kavramları yanlış anlama/ algılama & SÖ5, SÖ6, SÖ8, SÖ9, SÖ11, SÖ16, SÖ18, & 7 \\
Kavram anlamını karıştırma & SÖ3, SÖ17, SÖ19, SÖ20, SÖ21 & 5 \\
Yanlış ifade etme & SÖ2, SÖ7 & 2 \\
Farklı anlam yükleme & SÖ1, SÖ4, SÖ14, SÖ22 & 4 \\
Bilimsel anlamı dışında kullanma & SÖ12, SÖ15, SÖ10, SÖ13 & 4 \\
\hline
\end{tabular}

Tablo 1 incelendiğinde araştırmaya katılan öğretmenler tarafından kavram yanılgısına ilişkin tanımları 5 kategoride incelenmiştir. Bu tanımlardan "kavramları yanlış anlama/ algılama $(\mathrm{f}=7)$ " öğretmenlerin en çok yaptığı kavram yanılgısı tanımı olmakla beraber; kavram anlamını karıştırma ( $\mathrm{f}=5)$, Yanlış ifade etme ( $\mathrm{f}=2)$, farklı anlam yükleme ( $\mathrm{f}=4$ ) bilimsel anlamı dışında kullanma (f=4) katılımcı öğretmenlerin yaptığı diğer tanımlardır. Katılımcı öğretmenlerin görüşlerinden bazıları şu şekildedir;

"Bir kavramın bilimsel anlamı dışında farklı olarak ifade edilmesidir." (SÖ10) 
"Kavramlara olması gerektiği gibi değil de farklı bir anlam yükleme. Gerçek anlamı dışında algılama diyebiliriz." (SÖ1)

"Kavramın doğru anlaşılmaması veya başka bir kavramla karıştırılması." (SÖ20)

"Kavramları algılarken yanlış ifade etmektir" (SÖ7)

Araştırmanın Problemine Göre Katılımcı Öğretmenlerin Kavram Yanılgısının Sebeplerine İlişkin Görüşleri

Araştırmanın problemine göre katılımcı öğretmenlerin kavram yanılgısının nasıl oluştuğuna ilişkin görüşleri Tablo 2'de verilmiştir.

Tablo 2.

Araştırmanın problemine göre katılımcı öğretmenlerin kavram yanılgısının sebeplerine ilişkin görüşleri

\begin{tabular}{lcc}
\hline Oluşma şekli & Katılımc1 No & $f$ \\
\hline Bilgi eksikliği & SÖ2, SÖ9, SÖ12, SÖ16, SÖ17, SÖ20, SÖ21 & 7 \\
Yanlış alg1lama & SÖ5, SÖ11, SÖ13, SÖ15, SÖ22 & 5 \\
Konu üzerinde durulmamas1 & SÖ1, SÖ14 & 2 \\
Anlamamak & SÖ7, SÖ18 & 2 \\
Okuma yetersizliği & SÖ3, SÖ8 & 2 \\
Kavramları karıştırma & SÖ6, SÖ19, SÖ4 \\
Ezber & SÖ10 & 3 \\
\hline
\end{tabular}

Tablo 2 incelendiğinde "Bilgi eksikliği ( $(\mathrm{f}=7)$ ", Yanlış algılama ( $\mathrm{f}=5)$, farklı anlam yükleme ( $\mathrm{f}=4)$ bilimsel anlamı dışında kullanma $(\mathrm{f}=4)$ katılımcı öğretmenlerin en çok belirttiği kavram yanılgısı sebepleridir. Kavramları karıştırma (f=3), Konu üzerinde durulmaması (f=2), Anlamamak (f=2), Okuma yetersizliği $(\mathrm{f}=2)$, Ezber $(\mathrm{f}=1)$ daha az belirttikleri sebeplerdir. Katılımcı öğretmenlerin görüşlerinden bazıları şu şekildedir;

“...Öğrenciler daha önce kavramları ailelerinden, arkadaşlarından, TV ve internetten eksik ya da yanlış öğrenmiş olabilecekleri gibi kelime benzerliğinden kaynaklanabilmektedir. Kavramları anlatan öğretmenler kendileri bildikleri kavramı öğrencilerin de bildiğ i gibi bir hisle birçok örnek vermeden yani tam olarak somutlaştırmadan içini doldurmadan öğrencinin anladı̆̆ıı var sayarak geçtiğinde, öğrencide kavram öğrenme ya hiç gerçekleşmemekte yada eksik ve yanlış olarak gerçekleşmektedir." (SÖ14)

"Konuların öğrenci tarafindan yanlış algılanması, konu içinde geçen yabancı kelimeler, bilgi eksikliği, öğretmenler tarafından yanlış öğretilmesi gibi birçok nedenden dolayı oluşabilir." (SÖ22)

"Anlatılan konuyu dinlememek ya da tam anlamamakla oluşmaktadır." (SÖ7)

Araştırmanın Problemine Göre Katılımcı Öğretmenlerin Kavram Yanılgısını Nasıl tespit Ettiklerine İlişkin Görüşleri 
Araştırmanın Problemine Göre Katılımcı Öğretmenlerin Kavram Yanılgısını Nasıl tespit Ettiklerine İlişkin Görüşleri Tablo 3'te verilmiştir.

\section{Tablo 3.}

Araştırmanın problemine göre katılımo öğretmenlerin kavram yanılgısını nasıl tespit ettiklerine ilişkin görüşleri

\begin{tabular}{lcc}
\hline Yöntem & Kat1lımc1 No & $f$ \\
\hline Soru-Cevap & SÖ2, SÖ7, SÖ8, SÖ9, SÖ10, SÖ12, SÖ14, & 9 \\
Etkinlik & SÖ16, SÖ21 & 3 \\
Ölçme ve Değerlendirme & SÖ3, SÖ15, SÖ22 & 3 \\
Ön bilgileri kontrol etme & SÖ1, SÖ19, SÖ20 & 3 \\
Öğrenci cümlelerinden anlama & SÖ4, SÖ17, SÖ18 & 3 \\
\hline
\end{tabular}

Tablo 3'te incelendiğinde öğretmenler kavram yanılgısını en çok "soru-cevap" (f=9) ile tespit ettiklerini belirtmişlerdir. Bunun dışında Etkinlik ( $f=3$ ), Ölçme ve Değerlendirme ( $f=3$ ), Ön bilgileri kontrol etme ( $\mathrm{f}=3$ ), Öğrenci cümlelerinden anlama $(\mathrm{f}=3)$, katılımcı öğretmenlerin belirttiği diğer öğrencilerindeki kavram yanılgılarını tespit etme yöntemleridir. Katılımcı Öğretmenlerin görüşlerinden bazıları şu şekildedir;

"Dersimizin ünitesinde ilgili kavramları öğrencilere vererek bu kavramlarm onlarda neler çă̆rıştırdığını anlatmalarını isteyerek tespit ediyorum" (SÖ17)

"Bizim dersimizde kavramları bilmek çok önemli olduğu için dersi anlatırken kavramlar üzerinde fazlasıyla durmak gerekmektedir. Öğrencilere sorulan sorular ya da öğrencilerin bize sordŭ̆u sorulardan kavram bilgisi eksikliği ya da kavram yanılgısı olduğu tespit edilebilmektedir." (SÖ14)

“Ders esnasında öğrencilerin konuyla ilgili görüşlerini alırken, konu pekiştirme amaçlı hazırladığım kazanım değerlendirmelerde, bu tür stnavlarda bilgi sorularına onların içinde de kavram sorularına mutlaka yer veriyorum" (SÖ15)

\section{Araştırmanın Problemine Göre Öğretmenlerin Literatürdeki “Paralel” ve "Meridyen" Kavram Yanılgısına İlişkin Görüşleri}

Araştırmanın problemine göre katılımcı öğretmenlerin literatürdeki "paralel" ve "meridyen" kavram yanılgısına ilişkin görüşleri incelendiğinde 4 öğretmen bu kavramlara ilişkin kavram yanılgısı yaşanmadığını belirtirken diğer $(\mathrm{f}=18)$ öğretmenler bu kavramlara ilişkin kavram yanılgısının yaşandığına ilişkin görüş birliği içerisindedir. Bu kavramlara ilişkin kavram yanılgısı tespit eden öğretmenlerin bu kavram yanılgısını nasıl düzelttiklerine ilişkin görüşleri Tablo 4'te incelenmiştir;

Tablo 4.

Katılımcı ögrretmenlerin "Paralel" ve "Meridyen" Kavram Yanılgısını Nasıl Düzelttiklerine İlişkin Görüşleri

\begin{tabular}{lll}
\hline Yöntem & Katılımcı No & $f$ \\
\hline
\end{tabular}




\begin{tabular}{lcc}
\hline Somut materyal & SÖ1, SÖ9, SÖ10, SÖ14, SÖ21, SÖ22 & 6 \\
Görselleştirme & SÖ7, SÖ8, SÖ15, SÖ17 & 4 \\
Matematik yardımı ile & SÖ3, SÖ12, SÖ18, SÖ20 & 4 \\
Konu Pekiştirme & SÖ5, SÖ19, SÖ6, SÖ3 & 4 \\
\hline
\end{tabular}

Tablo 4 incelendiğinde öğretmenler literatürdeki "paralel" ve "meridyen" kavram yanılgisına ilişkin en çok "somut materyal" ( $\mathrm{f}=6$ ) ile kavram yanılgısını düzelttiklerini belirtmişlerdir. Bunun dışında görselleştirme ( $\mathrm{f}=4)$, matematik yardımı ile $(\mathrm{f}=4)$, konu pekiştirme $(\mathrm{f}=4)$, katılımcı ögretmenlerin belirttiği diğer öğrencilerindeki "paralel" "meridyen" kavramlarına yönelik kavram yanılgılarını düzeltme yöntemleridir. Katılımcı Öğretmenlerin görüşlerinden bazıları şu şekildedir;

“... Portakal ve mandalina çok iyi bir kavram pekiştirici bu konuda. Öğren getirdikleri mandalinayı soyup dilimleri inceliyorlar. Mandalina nın M'si meridyen olarak kodluyorsunuz. Portakaln ise yan yatırarak halkalar halinde kesiyorsunuz. Portakalın $p$ si ise paralel kodlaması oluyor." (SÖ1)

"Birini diğerinin yerine kullanma. Küre üzerinde öğrencinin paralel ve meriyedyen çizgilerini takip ettrilerek. Açılama yaparak. Matematik parelel doğrular kavramı ile ilişkilendirilerek. (SÖ20)

"Çok sık karıştırlan kavramlar maalesef. Tablolar, çalışma yapraklar yöntemiyle düzeltmeye çalıştım. Ayrıca iki ayrı küçük top üzerinde çizim oluşturarak gösterip yaptırma yöntemini denedim." (SÖ22)

“...Bunun önüne geçebilmek için konuyla ilgili bol görselli ve harita bilgisi gerektirecek etkinlikler yapıyorum ki kahıı ve doğru öğrenebilsin diye. Özellikle eğitsel oyunlar bu konuda çok işe yarıyor." (SÖ15)

Araştırmanın Problemine Göre Öğretmenlerin Literatürdeki “Kutup dairesi”, “Kutup Noktası”, “Güney yarım küre”, “Kuzey yarım küre” “Kavram Yanılgısına İlişkin Görüşleri

Katılımcı öğretmenlerden 3'ü literatürdeki "Kutup dairesi”, “Kutup Noktası”, “Güney yarım küre”, "Kuzey yarım küre” kavramlarına ilişkin öğrencilerde kavram yanılgısının olmadığını belirtmiştir. Diğer ( $\mathrm{f}=19)$ öğretmen bu kavramlara ilişkin kavram yanılgısının olduğunu belirtmiştir. Bu kavramlara ilişkin kavram yanılgısı tespit eden öğretmenlerin bu kavram yanılgısını nasıl düzelttiklerine ilişkin görüşleri Tablo 5'te incelenmiştir;

Tablo 5.

Katılımo öğretmenlerin "Kutup dairesi", "Kutup Noktası", "Güney yarım küre", "Kuzey yarım küre" kavram yanılgısını nasıl düzelttiklerine ilişkin görüşleri

\begin{tabular}{lcc}
\hline Yöntem & Katılımc1 No & $f$ \\
\hline Görseller & SÖ4, SÖ7, SÖ10, SÖ16, SÖ17, SÖ18, SÖ21 & 7 \\
Somut materyal (Yer Küre) & SÖ1, SÖ2, SÖ3, SÖ9, SÖ11, SÖ20 & 6 \\
Etkinlikler & SÖ14, SÖ16, SÖ22 & 3 \\
Konu pekiştirme & SÖ5, SÖ6, SÖ12 & 3 \\
\hline
\end{tabular}


Tablo 5 incelendiğinde öğretmenler "Kutup dairesi”, “Kutup Noktası”, “Güney yarım küre”, "Kuzey yarım küre" kavram yanılgısına ilişkin en çok "Görseller" (f=7) ile kavram yanılgısını düzelttiklerini belirtmişlerdir. Bunun dişında Somut materyal (Yer Küre ile) (f=6), Etkinlikler ile $(\mathrm{f}=4)$, konu pekiştirme ( $\mathrm{f}=3)$, katılımcı öğretmenlerin belirttiği diğer öğrencilerindeki "Kutup dairesi”, “Kutup Noktası", “Güney yarım küre”, “Kuzey yarım küre” kavramlarına yönelik kavram yanılgılarını düzeltme yöntemleridir. Öğretmenlerin görüşlerinden bazıları şu şekildedir;

"Bu konularla ilgili ne kadar çok etkinlik yapılırsa ve yine ne kadar çok görsel kullanılırsa o kadar faydalı oluyor." (SÖ14)

"Şekil çizerek yani dünya küresi çizerek ve çocuklara da çizdirerek öğretmek bu kavramların doğru öğrenilmesini să̆lıyor" (SÖ18)

"Yine Balon örneği üzerinde ile çizerek anlatmaya çalışıyorum." (SÖ16)

"Yer Küre üzerinde yapılan uygulamalarla düzeltiyorum." (SÖ11)

\section{Araştırmanın Problemine Göre Öğretmenlerin Literatürdeki “Özel Konum”, “Matematiksel Konum” Kavram Yanılgısına İlişkin Görüşleri}

Katılımcı öğretmenlerden yedisi literatürdeki "özel konum", "matematiksel konum" kavramlarına ilişkin öğrencilerde kavram yanılgısının olmadı̆̆ını belirtmiştir. Diğer (f=15) öğretmen bu kavramlara ilişkin kavram yanılgısının olduğunu belirtmiştir. Bu kavramlara ilişkin kavram yanılgısı tespit eden öğretmenlerin bu kavram yanılgısını nasıl düzelttiklerine ilişkin görüşleri Tablo 6'da incelenmiştir.

\section{Tablo 6.}

Katılımcı öğretmenlerin "özel konum", "matematiksel konum" kavram yanılgısını nasıl düzelttiklerine ilişkin görüşleri

\begin{tabular}{lcc}
\hline Yöntem & Katılımc1 No & $f$ \\
\hline Konu pekiştirme & SÖ2, SÖ3, SÖ4, SÖ9, SÖ10, SÖ12, SÖ19, SÖ20, SÖ21, SÖ22, & 10 \\
Soru çözme & SÖ5, SÖ13 & 2 \\
Somutlaştırma & SÖ1, SÖ6 & 2 \\
Görselleştirme & SÖ7 & 1 \\
\hline
\end{tabular}

Tablo 6 incelendiğinde katılımcı öğretmenler “özel konum”, “matematiksel konum” kavramlarına ilişkin kavram yanılgısına ilişkin en çok "Konu pekiştirme" ( $\mathrm{f}=10)$ ile kavram yanılgısını düzelttiklerini belirtmişlerdir. Bunun dışında Soru çözme ( $f=2)$, Etkinlikler ile ( $f=4)$, Somutlaştırma $(\mathrm{f}=2)$, Görselleştirme $(\mathrm{f}=1)$ katılımcı öğretmenlerin belirttiğ $\mathrm{i}$ diğer öğrencilerindeki “özel konum”, "matematiksel konum" kavramlarına yönelik kavram yanılgılarını düzeltme yöntemleridir. Öğretmenlerin görüşlerinden bazıları şu şekildedir;

"Yine çok karıştırılan iki kavram. Tam bir baş belası. Yine örneklendirme en iyi yöntem diye düşünüyorum. Şöyle ki tahtayı ekvator çizgisi olarak düşünmelerini ve oturdukları sırayı tahtaya yakınlık uzaklık olarak avantaj ve dezavantaj olarak değerlendirmelerini istiyorum buradan yola çıkarak 
matematiksel konumu ilişkilendiriyorum. Sonra yine diğer sıralara göre oturdukları sırayı sahip oldŭ̆u ayrıcalıklar olarak anlatmaların istiyorum işte bu da özel konum diyorum." (SÖ1)

"Bu kavramı karıştırabiliyorlar bunu da paralel meridyen kavramından yola çıkarak matematik konumla eşleştirdim özel konumu da Türkiye'nin özellikleri ile özel konumu beraber anlatarak bu yanılgıyı ortadan kaldırmaya çalışırım" (SÖ10)

"İşin içinde sayısal veriler (paralel, meridyen) varsa matematik konumla ilgili olduğunu basit bir mantıkla oturtuyorlar. O yüzden konumla ilgili kavram yanılgısı pek yaşamıyorlar diyebilirim.." (SÖ15)

“Türkiye ve Dünya üzerinden örnekler vererek pekiştiriyorum.” (SÖ7)

\section{Araştırmanın Problemine Göre Öğretmenlerin Literatürdeki “Heyelan", "Erozyon" Kavram Yanılgısına İlişkin Görüşleri}

Katılımcı öğretmenlerden ikisi literatürdeki "Heyelan”, “Erozyon” kavramlarına ilişkin öğrencilerde kavram yanılgısının olmadığını belirtmiştir. Diğer $(\mathfrak{f}=20)$ öğretmen bu kavramlara ilişkin kavram yanılgısının olduğunu belirtmiştir. Bu kavramlara ilişkin kavram yanılgısı tespit eden öğretmenlerin bu kavram yanılgısını nasıl düzelttiklerine ilişkin görüşleri Tablo 7'de incelenmiştir.

\section{Tablo 7.}

Katılımcı öğretmenlerin "heyelan", "erozyon" kavram yanılgısını nasıl düzelttiklerine ilişkin görüşleri

\begin{tabular}{lcc}
\hline Yöntem & Kat1lımc1 No & $f$ \\
\hline Görsel materyal (video, fotoğraf vb.) & $\begin{array}{c}\text { SÖ2, SÖ5, SÖ9, SÖ10, SÖ12, SÖ14, SÖ15, } \\
\text { SÖ18, SÖ20, SÖ21, SÖ22 }\end{array}$ & 11 \\
Konu pekiştirme & SÖ3, SÖ8 & 2 \\
Örneklerle pekiştirme & SÖ6, SÖ13, SÖ16, SÖ7 & 4 \\
Kodlama & SÖ1 & 1 \\
Deney & SÖ19 & 1 \\
\hline
\end{tabular}

Tablo 7 incelendiğinde katılımcı öğretmenler "Heyelan", "Erozyon" kavramlarına ilişkin kavram yanılgısına ilişkin en çok "Görsel materyal" (f=11) ile kavram yanılgısını düzelttiklerini belirtmişlerdir. Bunun dışında Konu pekiştirme ( $\mathrm{f}=2)$, Örneklerle pekiştirme ile $(\mathrm{f}=4)$, Deney ( $\mathrm{f}=1)$, Kodlama ( $\mathrm{f}=1$ ) katılımcı öğretmenlerin belirttiği diğer öğrencilerindeki bu kavramlara yönelik kavram yanılgılarını düzeltme yöntemleridir. Öğretmenlerin görüşlerinden bazıları şu şekildedir;

"Örnek olaylar ile iki kavram arasındaki farkı gösteriyorum. İklim ve yer şekilleri ile ilişkilendirerek öğrenci de kalıcı olmasını amaçlıyorum." (SÖ16)

“Ders esnasında masa üzerinde deney yapıyorum." (SÖ19)

"Evet bu iki kavramla ilgili yanılg̨ çok oluyor, bunda medyanın, kaynak kitaplarda yer alan yanlı̧ bilgilerin de etkisi var yanlış öğrenilmiş bir kavramı doğrusuyla değiştirmek zor oluyor geriye ket 
vuruyor bu durumlarda öğrenci. Ben bol görsel gösteriyorum bu konuyla ilgili, toprak aşınması ve toprak kayması kavramların yerleştiriyorum bu aşamada videolar çok etkili oluyor. Güncel fotoğraflar paylaşıyorum, sonuçta anlaşılıp anlaşılmadığııı ölçmek için bol görsel kullanarak hazırlanmış eğitsel oyunlar oynuyoruz." (SÖ15)

"Evet, görsel karşılaştırma ve yaşanmış video örnekleri izleterek düzelttim." (SÖ22)

\section{Araştırmanın Problemine Göre Öğretmenlerin Literatürdeki "Milli Egemenlik", "Bağımsızlık" Kavram Yanılgısına İlişkin Görüşleri}

Katılımcı öğretmenlerden sadece bir öğretmen literatürdeki "Milli Egemenlik”, "Bağımsızlık kavramlarına ilişkin öğrencilerde kavram yanılgısının olmadığını belirtmiştir. Diğer (f=21) öğretmen bu kavramlara ilişkin kavram yanılgısının olduğunu belirtmiştir. Bu kavramlara ilişkin kavram yanılgısı tespit eden öğretmenlerin bu kavram yanılgısını nasıl düzelttiklerine ilişkin görüşleri Tablo 8' de incelenmiştir.

\section{Tablo 8.}

Katılımcı öğretmenlerin "milli egemenlik", "bağımsızlık" kavram yanılgısını nasıl düzelttiklerine ilişkin görüşleri

\begin{tabular}{lcc}
\hline Yöntem & Kat1lımc1 No & $f$ \\
\hline Örnekler & SÖ9, SÖ11, SÖ13, SÖ14, SÖ20, SÖ21, & 6 \\
Etkinlik & SÖ1, SÖ2, SÖ3, SÖ5, SÖ15, SÖ22 & 6 \\
Konu pekiştirme & SÖ6, SÖ7, SÖ8, SÖ10, SÖ18, SÖ19 & 6 \\
Soru çözümü & SÖ12, SÖ16 & 2 \\
\hline
\end{tabular}

Tablo 8 incelendiğinde katılımcı öğretmenler ““"Milli Egemenlik”, “Bağımsızlık” kavramlarına ilişkin kavram yanılgısına ilişkin en çok "Örnekler" ( $\mathrm{f}=6)$, Etkinlik ( $\mathrm{f}=6)$, Konu pekiştirme ( $\mathrm{f}=6$ ) ile kavram yanılgısını düzelttiklerini belirtmişlerdir. Bunun dışında Soru çözümü $(\mathrm{f}=2)$, katılımcı öğretmenlerin belirttiği diğer öğrencilerindeki bu kavramlara yönelik kavram yanılgılarını düzeltme yöntemidir. Öğretmenlerin görüşlerinden bazıları şu şekildedir;

“En çok karıştırılan kavram yanılgısına düşülen iki kavram diyebiliriz. Öğrenciler bu iki kavramı ayırmakta ve zihinlerine doğru konumlandırmakta zorlanmaktadırlar. Bu yanılgıyı düzeltmek için etkili örnekler vermek gerek mesela Osmanlı bağımsız bir devletti ama milli egemenlik yoktu gibi. Tabi önce egemenlik ve milli kavramlarının yine içi doldurularak çarpıcı örneklerle açıklamak gerek." (SÖ14)

“Bă̆ımsızlı̆̆l, hür, özgür olma; egemenlik kavramını gücü etkince tutma olarak ifade ediyorum. Mesela sinıfta kim egemen şu an, diyorum. Siz diyorlar. Yani sinıf bir potansiyel güç ve bu gücü şu an ben elimde tutuyorum, diyorum. Ben yokken kim diyorum. Sını başkanı diyorlar. Okulda müdür vs." (SÖ5)

"Milli egemenlik ilkesini cumhuriyet yönetiminden yola çıkarak ki kongre maddelerinden örneklerle kavratıyorum bă̆ımsızlık ilkesini bă̆ımsızlık kapitülasyonlar vb bağlantı kurarak anlatıyorum" (SÖ10) 
"Milli bağımsızlık kavramı için sömürge olan veya himaye edilen devletlerin durumunu örnek veririm genelde. Milli egemenlik için Osmanlı ile Cumhuriyeti karşılaştırırım." (SÖ18)

\section{Araştırmanın Problemine Göre Öğretmenlerin Literatürdeki "Fetih", “İskân" Kavram Yanılgısına İlişkin Görüşleri}

Katılımcı öğretmenlerden 9 öğretmen literatürdeki "Fetih", "İskân” kavramlarına ilişkin öğrencilerde kavram yanılgısının olmadığını belirtmişlerdir. Arıca bir öğretmen sadece iskân kavramında, bir öğretmen ise sadece fetih kavramında yanılgı yaşadığını belirtmiştir. Diğer (f=13) öğretmen bu kavramlara ilişkin kavram yanılgısının olduğunu belirtmiştir. Bu kavramlara ilişkin kavram yanılgısı tespit eden öğretmenlerin bu kavram yanılgısını nasıl düzelttiklerine ilişkin görüşleri Tablo 9'da incelenmiştir.

Tablo 9.

Katılımcı öğretmenlerin "fetih", "iskân" kavram yanılgısını nasıl düzelttiklerine ilişkin görüşleri

\begin{tabular}{lcc}
\hline Yöntem & Katılımc1 No & $f$ \\
\hline Örnekle pekiştirme & SÖ1, SÖ3, SÖ6, SÖ9, SÖ11, SÖ13, SÖ20 & 8 \\
Kavram tanımı pekiştirme & SÖ5, SÖ10, SÖ18 & 3 \\
Hikâye metinleri & SÖ8, & 1 \\
Soru sorarak pekiştirme & SÖ14 & 1 \\
\hline
\end{tabular}

Tablo 9 incelendiğinde katılımcı öğretmenler "Fetih", "İskân" kavramlarına ilişkin kavram yanılgısına ilişkin en çok "Örnekle pekiştirme" (f=8), Kavram tanımı pekiştirme (f=3) ile kavram yanılgısını düzelttiklerini belirtmişlerdir. Bunun dışında hikâye metinleri ( $\mathrm{f}=1)$, Soru sorarak pekiştirme (f=1) katılımcı öğretmenlerin belirttiği diğer öğrencilerindeki bu kavramlara yönelik kavram yanılgılarını düzeltme yöntemidir. Öğretmenlerin görüşlerinden bazıları şu şekildedir;

"Aslında pek karıştırılan bir kavram değil. Fetihi Fatih unvanını örnek vererek pekiştirilebiliyor. (İstanbul'un fethi). İskân biraz zorluyor. Mesken kelimesi ile iskân arasında bă̆ kurarak yerleşmeyi açıklıyorsunuz. İskân ile ilgili haber başlıkları kullanılabiliyor. İşte şu kadar göçmen işe şu ilimize iskân edildi gibi. Bu haberde anlatılan nedir gibi." (SÖ1)

"Fetih kelimesini İstanbul un fethi ile anlatırdım sonra iskân kelimesini balkanlarda fethedilen yerlere yerleşme kavramı ile beraber anlatıyorum bunu resim vb. şekillerle de somutlaştırıyorum" (SÖ9)

“Öğrenciye iskân kavramının Müslüman olmayan topraklarda gerçekleştiğini anlatıyorum. Fetih örneklerinden burada iskân olur mu diye soru sorarak ayrım yapıyorum." (SÖ14)

"Fetih kavramı işgal kavramı ile karıştırılıyor. Fetih anlayışını tarihsel anlamında anlatmaya özen gösterdim" (SÖ4)

\section{SONUÇ VE TARTIŞMA}

Bu çalışmada literatürdeki sosyal bilgiler öğretim programı içeriğinde yer alan kavramlara yönelik kavram yanılgılarının sosyal bilgiler öğretmenlerinin görüşlerine göre incelenmiştir. 
Literatürdeki araştırmalar temel alınarak Öğretmenlerin sosyal bilgiler dersi öğretim programı içerisinde yer alan "paralel, meridyen, kutup dairesi, kutup noktası, Güney Yarım Küre, Kuzey Yarım Küre, özel konum, matematiksel konum, iklim, hava durumu, heyelan, erozyon, bağımsızlık, milli egemenlik, fetih, iskân" kavramlarına ilişkin "kavram yanılgısı" görüşlerinin incelenmesi bu kavram yanılgılarının kendi öğrencilerindeki durumlarına yönelik görüş ve deneyimlerinin incelenmiştir.

Araştırma bulgularından yola çıkarak elde edilen sonuçlara göre katılımcı öğretmenlerin kavram yanılgılarını kavramları yanlış anlama/ algılama, kavram anlamını karıştırma, yanlış ifade etme, farklı anlam yükleme ve kavramın bilimsel anlamı dışında kullanma olarak tanımladıkları tespit edilmiştir. Katılımcı öğretmenlerin çoğunluğunun kavram yanılgısını tam manasıyla tanımlamada güçlük yaşadığı söylenebilir. Kavram yanılgılarının sebeplerine ilişkin Bilgi eksikliği (f=7), Yanlış algılama ( $\mathrm{f}=5)$, farklı anlam yükleme (f=4) bilimsel anlamı dışında kullanma $(\mathfrak{f}=4)$ katılımcı öğretmenlerin en çok belirttiği sebeplerdir. Kavramları karıştırma ( $\mathrm{f}=3$ ), Konu üzerinde durulmaması $(\mathrm{f}=2)$, Anlamamak $(\mathrm{f}=2)$, Okuma yetersizliğ $(\mathrm{f}=2)$, Ezber $(\mathrm{f}=1)$ en az belirtilen sebeplerdendir. Araştırma bulgularından elde edilen sonuca göre öğretmenler kavram yanılgısını en çok "soru-cevap" (f=9) ile tespit ettiklerini belirtmişlerdir. Bunun dişında Etkinlik ( $f=3$ ), Ölçme ve Değerlendirme ( $f=3$ ), Ön bilgileri kontrol etme (f=3), Öğrenci cümlelerinden anlama (f=3), katılımcı öğretmenlerin belirttiğ diğer öğrencilerindeki kavram yanılgılarını tespit etme yöntemleridir.

Katılımcı öğretmenlerin çoğunluğu (f=18) Paralel ve meridyen kavramlarına ilişkin öğrencilerde kavram yanılgısının olduğunu belirtmiştir. Elde edilen bu sonuç Boz (2019) yaptığı yüksek lisans tez çalışmasında öğrencilerin paralel ve meridyen kavramlarını anlama düzeylerinin düşük olduğu ve çok sayıda yanlış anlamaya sahip oldukları bulgusuyla paralellik göstermektedir. Bu sonuç Akbaş (2002), Kayacan (2010), Gülüm (2010), Demirkaya ve Karacan (2016), Bitlisli (2014), Gümüş ve Avcı (2016), Memişoğlu ve Tarhan (2016), Özdoğan (2016) yapmış oldukları çalışmalarda öğrencilerin paralel ve meridyen kavramlarına ilişkin kavram yanılgılarına sahip olması sonucuyla örtüşmektedir. Katılımcı öğretmenler literatürdeki "paralel" ve "meridyen" kavram yanılgısına ilişkin en çok "somut materyal" $(\mathrm{f}=6)$ ile kavram yanılgısını düzelttiklerini belirtmişlerdir. Bunun dışında görselleştirme ( $\mathrm{f}=4)$, matematik yardımı ile $(\mathfrak{f}=4)$, konu pekiştirme $(\mathfrak{f}=4)$, katılımcı öğretmenlerin belirttiği diğer öğrencilerindeki "paralel” "meridyen" kavramlarına yönelik kavram yanılgılarını düzeltme yöntemleri olduğu sonucuna ulaşılmıştır.

Katılımcı öğretmenlerin çoğunluğu (f=19) "kutup dairesi”, “kutup noktası”, "güney yarım küre", "kuzey yarım küre" kavramlarına ilişkin öğrencilerde kavram yanılgısının olduğunu belirtmiştir. Bu sonuç literatürdeki; Gümüş ve Avcı (2016), Demirkaya ve Karacan (2016), Özdoğan (2016), Akbaş (2002) ve Gülüm (2010) yaptığı çalışmalardan elde ettikleri sonuçlarla örtüşmektedir. Katılımcı öğretmenler "Kutup dairesi”, "Kutup Noktası”, "Güney yarım küre", "Kuzey yarım küre" kavram yanılgısına ilişkin en çok "Görseller" (f=7) ile kavram yanılgısını düzelttiklerini belirtmişlerdir.

Katılımcı öğretmenler (f=15) “özel konum", "matematiksel konum” kavramlarına ilişkin öğrencilerde kavram yanılgısının olduğunu belirtmiştir. Akdağ (2010) yaptığ1 araştırmada paralel-meridyen, özel konum-matematik konum kavramlarının birbirine karıştırıldığını 
tespit ettiği sonucuyla paralellik göstermektedir. Boz (2019) öğrencilerin özel konumla adres, harita ve matematik konum gibi kavramları karıştırdıkları sonucuna ulaşmıştır. Bu sonuç literatürde yapılan diğer; Akbaş (2002), Bitlisli (2014), Demirkaya ve Karacan (2016), Özdoğan (2016) çalışmaları desteklemektedir. Katılımcı öğretmenler “özel konum”, "matematiksel konum" kavramlarına ilişkin kavram yanılgısına ilişkin en çok "Konu pekiştirme" ( $\mathrm{f}=10$ ) ile kavram yanılgısını düzelttiklerini belirtmişlerdir.

Katılımcı öğretmenler (f=20) literatürdeki "Heyelan”, “Erozyon” kavramlarına ilişkin öğrencilerde kavram yanılgısının olduğunu belirtmiştir. Bu sonuç literatürde yer alan Açıkgöz (2007), Bozkurt, Akın ve Uşak (2004), Pınar ve Akdağ (2012), Yıllar (2007), Boz (2019) araştırmalarında öğrencilerin erozyon kavramını anlama düzeylerinin düşük olduğu ve birçok kavram yanılgısına sahip oldukları sonuçlarıyla paralellik göstermektedir. Katılımcı öğretmenler "Heyelan”, "Erozyon” kavramlarına ilişkin kavram yanılgısına ilişkin en çok "Görsel materyal" (fotoğraf, video vb.) (f=11) ile kavram yanılgısını düzelttiklerini belirtmişlerdir.

Katılımcı öğretmenler (f=21) literatürdeki "Milli Egemenlik", "Bağımsızlık kavramlarına ilişkin öğrencilerde kavram yanılgısının olduğunu belirtmiştir. Bu sonuç literatürdeki Sabancı (2008), Gençmehmetoğlu (2009), Ünlü (2011), Kaya (2011), Akış \& Bal, (2010) Bal \& Gök (2011) taptıkları çalışmalardan elde ettikleri benzer sonuçlar araştırma sonucunu destekler niteliktedir. Araştırma bulguları Bozdoğan (2018) ve Ulusoy ve Yelken'in (2009) yapmış olduğu araştırmalarda milli egemenlik ve bağımsızlık kavramlarına ilişkin öğrencilerde kavram yanılgısını olmadığı sonucu bu araştırmanın bulgularıyla örtüşmemektedir. Katılımcı öğretmenler "Milli Egemenlik", "Bağımsızlık” kavramlarına ilişkin kavram yanılgısına ilişkin en çok "Örnekler" (f=6), Etkinlik $(\mathrm{f}=6)$, Konu pekiştirme $(\mathrm{f}=6)$ ile kavram yanılgısını düzelttiklerini belirtmişlerdir.

Katılımcı öğretmenlerden (f=9) "Fetih", “İskân” kavramlarına ilişkin öğrencilerde kavram yanılgısının olmadığını belirtmişlerdir. Diğer öğretmenler ( $f=13)$ bu kavramlara ilişkin kavram yanılgısının olduğunu belirtmiştir. Ayana (2018) yapmış olduğu tez çalışmasında "fetih kavramında" öğrencilerde büyük oranda kavram yanılgısı görüldüğü fakat "iskân" kavramında öğrencilerde nispeten daha az kavram yanılgısı tespit edildiği sonucuna ulaşmıştır. Yılmaz \& Çiviler (2012) yapmış oldukları çalışmada öğrencilerde "fetih" kavramına ilişkin kavram yanılgısına sahip olduğu tespit etmişlerdir. Akgün (2014) yapmış olduğu çalışmasında öğrencilerin "fetih" ve "iskân" kavramlarında kavram yanılgısına düştüklerini tespit etmiştir. Katılımcı öğretmenler "Fetih", "İskân" kavramlarına ilişkin kavram yanılgısına ilişkin en çok “Örnekle pekiştirme” ( $f=8)$, Kavram tanımı pekiştirme (f=3) ile kavram yanılgısını düzelttiklerini belirtmişlerdir

Araştırma bulgularından elde edilen sonuçlara göre sosyal bilgiler öğretmenlerinin görüşlerine göre öğrencilerin en çok "milli egemenlik", "bağımsızlık” kavramları başta olmak üzere "paralel, meridyen, kuzey yarım küre, güney yarım küre, kutup dairesi" gibi soyut coğrafi kavramları öğrenmede güçlük yaşadıkları ve kavram yanılgılarına sahip oldukları söylenebilir. Bu sonuç alan yazında yer alan; Akbaş, 2002 Sabancı, 2008; Gençmehmetoğlu, 2009; Akış \& Bal, 2010; Bal \& Gök, 2011; Kaya, 2011, Ünlü, 2011; Akdağ, 2010; Kayacan,2010; 
Gülüm, 2010; Bitlisli, 2014; Karacan \& Demirkaya, 2016; Gümüş \&Avc1 2016; Özdoğan, 2016; Memişoğlu \& Tarhan, 2016; Boz, 2019 yapmış oldukları araştırmalarda büyük ölçüde örtüşmektedir. Yıllar içerisinde yapılan çeşitli araştırmalar bu kavram yanılgılarına yönelik öğrencilerin sorunlar yaşadığını ortaya koymaktadır. Etkili bir sosyal bilgiler eğitiminin yapılabilmesi için kavram öğretimine önem verilmelidir. Kavram yanılgıları öğrencilerin ileriki öğrenmelerine de engel teşkil edebilmektedir. Buna göre bu alanda iyileştirme çalışmalarının artması gerekmektedir. Yapılan bu araştırmada ayrıca katılımcı öğretmenlerin ifadelerinden elde edilen sonuçlara göre öğretmenlerin öğrencilerdeki kavram yanılgılarını tespit edebilme ve bu kavram yanılgılarının düzeltilmesi noktasında kavram öğretimine yönelik yöntem ve teknik bilgilerinin eksik olduğu söylenebilir. Sosyal Bilgiler öğretim programlarında "kavram eğitimine" daha çok yer verilmelidir. Bakanlık ve ilgili uzmanlarca öğretmenlere kavram öğretimine yönelik kapsamlı eğitici kılavuzlarının hazırlanması önerilmektedir. Konuyla alakalı ara dönem ve yılsonunda bilgilendirme seminerleri verilmelidir.

\section{KAYNAKÇA}

Açıkgöz, A. (2007). Ortaöğretim 9. simıf öğrencilerinin heyelan, toprak kayması ve erozyon kavramların anlama düzeyleri ve kavram yanılgıları. Yayınlanmamış yüksek lisans tezi, Karadeniz Teknik Üniversitesi, Trabzon.

Akbas, Yavuz. (2002). İlköğretim 6. sinıf öğrencilerinin coğrafi kavramları anlama düzeyleri ve kavram yanılgıları. Karadeniz Teknik Üniversitesi Sosyal Bilimler Enstitüsü, Trabzon.

Akdağ, Ş. (2010). İlköğretim 6. sını öğrencilerinin "yeryüzünde yaşam" ünitesi'ndeki kavram yanılgıları. (Yayınlanmamış Yüksek Lisans Tezi). Afyon Kocatepe Üniversitesi Sosyal Bilimler Enstitüsü, Afyonkarahisar.

Akgün, İ. H. (2014). Sosyal bilgiler dersi 7. sınıf kültür ve miras öğrenme alanı “Türk Tarihine Yolculuk" ünitesinde geçen kavramların öğrenilme düzeyi. Turkish StudiesInternational Periodical for the Languages, Literature and History of Turkish or Turkic. 9 (5), 105-116.

Ayana, M. (2018). Sosyal bilgiler dersi "Ipek Yolunda Türkler" ünitesindeki kavram yanılgıları ve öğretmenlerin öğrencilerin kavram yanılgılar ile ilgili farkındalıklarının tespiti. Yayınlanmamış yüksek lisans tezi, Fırat Üniversitesi, Elazı ̆̆.

Aydoğan, S, Güneş, B, Gülçiçek, Ç. (2003). Isı ve sıcaklık konusunda kavram yanılgıları. Gazi Üniversitesi Gazi Ĕ̆gitim Fakültesi Dergisi, 23 (2).

Bal, M, Akış, A. (2010). Sosyal bilgiler dersi “insanlar ve yönetim” ünitesinde karşılaşılan kavram yanılg1ları. Education Sciences, 5 (4), 2061-2070.

Bal, M. S. Gök, S. (2011). İlköğretim 5. sınıf öğrencilerinin sosyal bilgiler dersindeki cumhuriyet, saltanat ve liderlik kavramlarını algılayışları. Gaziantep University Journal of Social Sciences, 10 (3), 1183-1198. 
Bitlisli, N. (2014). 6.sınf öğrencilerinin sosyal bilgiler dersi yeryüzünde yaşam ünitesinde geçen coğrafi kavramları algılama düzeyleri ve kavram yanılgıları (Bayburt örneği). Yayımlanmamış Yüksek Lisans Tezi. Giresun Üniversitesi Sosyal Bilimler Enstitüsü, Giresun.

Boz, E. (2019). Ortaokul öğrencilerinin temel coğrafi kavramlar anlama düzeyleri ve kavram yanılgıları (Amasya ili örneği). Yayınlanmamış yüksek lisans tezi, Amasya Üniversitesi. Amasya.

Bozdoğan, K. (2018). Ortaokul öğrencilerinin sosyal bilgiler öğretim programında yer alan tarih kavramlarına yönelik algılarının incelenmesi. Yayınlanmamış doktora tezi, Necmettin Erbakan Üniversitesi, Zonguldak.

Bozkurt, O., Salman Akın, B. ve Uşak, M. (2004). İlköğretim 6., 7. ve 8. sınıf öğrencilerinin erozyon hakkındaki ön bilgilerinin ve kavram yanılgılarının tespiti. Gazi Üniversitesi Kırşehir Ĕ̆itim Fakültesi Dergisi, 5(2), 277-285.

Creswell, J. W. (2007). Qualitative inquiry \& research design choosing among five approaches. second edition. London:Sage Publication.

Demirkaya, H, Karacan, H. (2016). Ortaokul 6. sınıf öğrencilerinin sosyal bilgiler dersindeki bazı coğrafi kavramları anlama düzeyleri ve kavram yanılgıları. Uluslararası Alan Ĕ̆itimi Dergisi, 2 (2), 38-57.

Erden, M. ve Akman, Y. (1997). Gelişim-öğrenme-öğretme. Ankara: Arkadaş Yayınevi.

Gençmehmetoğlu, R. (2009). VIII. sınıf Türkiye Cumhuriyeti İnkılap Tarihi ve Atatürkçülük dersinde yer alan olgu, kavram ve genellemelerin öğretimi ve önemi. (Yayımlanmamış yüksek lisans tezi). Atatürk Üniversitesi Sosyal Bilimler Enstitüsü, Erzurum.

Güçlü, İ. (2019). Sosyal Bilimlerde Nitel Araştırma Yöntemleri (teknik-yaklaşım-uygulama). Ankara: Nobel Yayıncilık.

Gülüm, K. (2010). Sosyal bilgiler öğretmenliği öğrencilerinin fiziki coğrafya konularındaki bazı temel kavramları anlama düzeyi ve kavram yanılgıları. Akademik Bakış Dergisi, (20), 1-10.

Gümüş, N. ve Avcı, G. (2016). Altıncı sınıflarda sosyal bilgiler dersinde öğrencilerin coğrafi kavramları anlama düzeyleri ve kavram yanılgılarının belirlenmesi. International Journal of Social Science 47, 191-206

Harwood, Doug; Jackson, Pamela. (1993). Why did they build this hill so steep? problems of assessing primary children's understanding of physical landscape features in the contexs of the UK national curriculum. Geographic And Environmental Education, (2), 2. $64-79$. 
Kaya, E. (2011). İlköğretim 7.sını öğrencilerinin bazı demokrasi kavramları hakkındaki görüşleri ve yanılgıları (Aksaray örneği). Yayımlanmamış yüksek lisans tezi, Niğde Üniversitesi. Niğde.

Kayacan, Z. (2010). Illköğretim altıncı sını öğrencilerinin coğrafi koordinatlarla ilgili kavram yanılgıları. Yayımlanmamış yüksek lisans tezi, Balıkesir Üniversitesi, Balıkesir.

Kılıçoğlu, G. (2011). Sosyal Bilgiler derslerinde kavramsal değişim metinlerinin kavram yanılgılarını giderme üzerine etkisi. Yayımlanmamış Doktora Tezi, Gazi Üniversitesi. Ankara.

Memişoğlu, H. ve Tarhan, E. (2016). Sosyal bilgiler öğretmenlerinin kavram öğretimine ilişkin görüşleri. Ĕ̆gitim ve Öğretim Araştırmaları Dergisi, (5), 6- 20.

Özdoğan, G. (2019). Sosyal bilgiler öğretmenlerinin 6.sınf öğrencilerinin harita bilgisi ve coğrafi koordinatlara ilişkin kavram yanılgılarına yönelik görüşleri. Yayınlanmamış yüksek lisans tezi. Mehmet Akif Ersoy Üniversitesi, Burdur.

Pınar, A. ve Akdağ, H. (2012). Sosyal bilgiler öğretmen adaylarının iklim, rüzgâr, sıcaklık, yağış, erozyon, ekoloji ve harita kavramlarını anlama düzeyi. İlköğretim Online, (11) 2, 530-542.

Platten, Linda. (1995a, Spring) Talking geography: an investigation into young children's understanding of geographical terms part-1. International Journal of Early Years Education, 3 (1), 74-91.

Prater, M. A. (1993). Teaching concepts: procedures for the design and delivery of instruction. Remedial and Special Education, 14 (5), 51-62.

Sabanc1, O. (2008), İlköğretim 7. sını öğrencilerinin sosyal bilgiler dersinde yer alan vatandaşlık konularıyla ilgili kavramsal anlamaları. Yayımlanmamış yüksek lisans tezi, Gazi Üniversitesi Eğitim Bilimleri Enstitüsü. Ankara

Sart, G. (2017). Fenomoji ve yorumlayıc fenomoloijk analiz. Seggie, F. N. \& Bayyurt, Y. (Ed.), Nitel Araştırma, Yöntem, Teknik, Analiz ve Yaklaşımları içinde (s.70-81). Ankara: Anı Yayıncilık

Senemoğlu, N. (2007). Gelişim öğrenme ve öğretim (kuramdan uygulamaya). Ankara: Gönül

Tokcan, H. (2015). Sosyal Bilgilerde Kavram Öğretimi. Ankara: Pegem A Yayınevi

Smith, J.A. and Osborn, M. (2008). Interpretive phenomenological analysis. In Smith, J.A. (ed) Qualitative Psychology: A Practical Guide to Research Methods, 2nd Ed. (pp. 53-80) London: Sage Publication.

Turan, İ. ve Kartal, A. (2012). İlköğretim beşinci sınıf öğrencilerinin doğal afetler konusu ile ilgili kavram yanılgıları. Ahi Evran Üniversitesi Kırşehir Ĕ̆itim Fakültesi Dergisi, 13(3), 67-81. 
Sosyal Bilgiler Öğretmenlerinin Literatürdeki Sosyal Bilgiler Dersi

Kavram Yanılgılarına İlişkin Görüşleri
JIRSS Cilt: 4 Sayı: 2

Türk Dil Kurumu [TDK] (2018). “Kavram" sözcüğü http://www.tdk.gov.tr/index.php?option=comşgts\&arama=gts\&guid=TDK.GTS.5875e 5ce129c42.00594692 adresinden 20.12.2020 tarihinde erişilmiştir.

Ulusoy, K., ve Yelken, T. Y. (2009). İlköğretim 4. ve 5. sınıf öğrencilerinin Atatürkçülük ile ilgili kavramları algılamaları. Sosyal Bilimler Dergisi, 22, 461 213-223.

Ülgen, G. (1996). Kavram geliştirme (kuramlar ve uygulamalar) (2.Baskı). Ankara: SETMA

Ünlü, F. (2011). Illköğretim sosyal bilgiler programında geçen temel kavramların 8. sını f̈ğrencilerinde erişi düzeyi. Yayımlanmamış yüksek lisans tezi, Celal Bayar Üniversitesi. Manisa.

Yıldırım, A. ve Şimşek, H. (2018). Sosyal Bilimlerde Nitel Araştırma Yöntemleri. 11. Baskı. Ankara: Seçkin Yayıncılık

Yıllar, B. (2007). İlköğretim 5. sınıf öğrencilerinin coğrafya kavramlarını anlama düzeyleri ve kavram yanılgıları. Yayınlanmamış yüksek lisans tezi, Atatürk Üniversitesi, Erzurum.

Yılmaz, K. ve Çiviler. M. (2012). İlköğretim 6. sınıf sosyal bilgiler dersi “Yeryüzünde Yaşam” ünitesinde yer alan tarih kavramlarının öğretiminde karşılaşılan kavram yanılgıları üzerine bir eylem araştırması. Türk Tarih Eğitimi Dergisi, 1(1) 